\title{
Autophagy-Related Protein 16-1
}

National Cancer Institute

\section{Source}

National Cancer Institute. Autophagy-Related Protein 16-1. NCI Thesaurus. Code C119725.

Autophagy-related protein 16-1 (607 aa, $\sim 68 \mathrm{kDa}$ ) is encoded by the human AT G16L1 gene. This protein plays a role in the mediation of autophagy. 